\title{
EKSTRADISI MENG WANZHOU DALAM PERSPEKTIF HUKUM INTERNASIONAL
}

\author{
Teddy Nurcahyawan \\ (Dosen Hukum Internasional Fakultas Hukum Universitas Tarumanagara) \\ (teddy_yureka@hotmail.com)

\section{Stevanus Rivaldo} \\ (Mahasiswa Program S1 Fakultas Hukum Universitas Tarumanagara)
}

Received: 20 Agustus 2019; Accepted: 03 September 2019; Published: 29 Oktober 2019

\begin{abstract}
Extradition is one of the international law field of studies. One of that controversy is Meng Wanzhou's case, chief financial officer of Huawei. She is known as the daughter of Huawei's founder Ren Zhengfei and holding Chinese citizenship. Meng Wanzhou was captured and detained by Canadian authority by the request of United States of America when she transitted Canada at Vancouver Airport December 2018. She was charged of frauding which is related to Skycom, a technology company based in Iran. This event led the diplomatic ralation between China, Canada and United States excalated. China government had already released an official statement which expressed anger and their objection about the charged and detention. On the other side, Canada and United States insisted in this event genuinely only a legal matter. This research conducted by a normative and IRAC methods for the analysis part. Based on the research, the request of extradition by United States was consistent with international law principle. Every objection matter by any Party of this case should be done by every diplomatic channels. This thing should be done to maintain the world's peace.
\end{abstract}

Keywords: international law, extradition, meng wanzhou.

\section{PENDAHULUAN}

\section{A. Latar Belakang}

Fiat iustitia et pereat mundus, let the justice be done though the world perish, it characterizes an attitude which wants to provide justice at any price. ${ }^{1}$ ) Istilah ini dalam bahasa

\footnotetext{
1) Andrew Benjamin, Walter Benjamin And Art, (London: Continuum, 2011), hal. 261.
}

Indonesia dikenal dengan 'biarlah hukum ditegakan walaupun langit runtuh'. Adagium ini menyatakan bahwa keadilan atau hukum harus ditegakan apapun yang terjadi sehingga tidak boleh ada satupun orang yang lolos dari hukuman atas kejahatan yang dilakukannya. Asas tersebut diperkuat lagi oleh asas aut dedere aut punere yang berarti a 
Teddy Nurcahyawan \& Stevanus Rivaldo Ekstradisi Meng Wanshou dalam Prespektif...

legal obligation of any states under international law to prosecute persons who commits international crimes. $^{2}$ ) Artinya adalah setiap negara memiliki kewajiban dalam hukum internasional untuk melakukan tindakan terhadap seseorang yang melakukan kejahatan internasional.

Dalam penegakan hukum, kerjasama antarnegara sangat penting jika terjadi suatu kejahatan yang dilakukan lintas batas negara. Penegakan hukum tersebut dilakukan dengan melakukan perjanjian bilateral ataupun multilateral. Perjanjian bilateral sendiri dapat dilakukan dalam bentuk suatu perjanjian ekstradisi. ${ }^{3}$ ) Ekstradisi sendiri sudah dikenal sebagai salah satu bentuk penegakan hukum yang tertua di dunia. Extradition can be traced as far back as th Egyptian, Chinese, Chaldean, and Assyro

2) Andre da Rocha Fereira, et. al., "The Obligation to Extradite or Prosecute", UFRGS Model United Nations Journal, Volume 1, 2013, hal. 202.

3) Artasasmita, Romli, "Ekstradisi dalam Meningkatkan Kerja Sama Penegakan Hukum", Indonesian Journal of International Law, Volume 3, Nomor 1, Oktober 2007.
Babylonian civilization. ${ }^{4}$ ) Artinya bahwa eksistensi konsep ekstradisi telah ada sejak peradaban Mesir, Tiongkok, Kasdim dan era Babilonia. Pelaksanaan ekstradisi bukanlah selalu tanpa masalah. Kasus yang baru-baru ini terjadi dalam dunia internasional adalah mengenai penangkapan Chief Financial of Officer (CFO) Huawei, Meng Wanzhou oleh pemerintah Kanada. Ia merupakan seorang warga negara Tiongkok dan anak dari pendiri perusahaan Huawei itu sendiri, Ren Zhengfei. Meng Wanzhou ditangkap oleh otoritas Kanada pada Sabtu tanggal 1 Desember 2018 saat transit di Bandara Vancouver. ${ }^{5)}$ Ia ditahan atas permintaan Pemerintah Amerika Serikat atas tuduhan melakukan misleading terhadap lembaga keuangan Amerika Serikat. Hal ini dilakukan sehingga membuat

\footnotetext{
4 ) M. Cherif Bassiouni, International Extradition and World Public Order, (Alphen aan den Rijn: Kluwer Academic Publisher, 1974), hal. 1.

5) Vebri, "4 Fakta Terbaru Setelah Bos Huawei Ditangkap: Mantan Diplomat Kanada Ditangkap di China”, http://www.tribunnews.com/section/2018/12/1 4/4-fakta-terbaru-setelah-bos-huaweiditangkap-mantan-diplomat-kanada-ditahanchina diakses pada tanggal 21 Januari 2018 pukul 14.00 .
} 


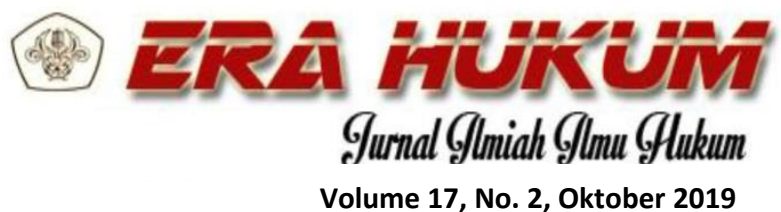

Volume 17, No. 2, Oktober 2019

lembaga keuangan tersebut melakukan transaksi keuangan dengan Iran. Padahal, Iran sendiri sedang diberi sanksi perdagangan oleh Amerika Serikat.

Pemberian sanksi oleh Pemerintah Amerika Serikat kepada Iran dilakukan dalam rangka untuk menekan Pemerintah Iran dalam program peluru kendali dan nuklir. The United States have imposed severe sanctions on Iran because of high distrust of the country's persuance of a nuclear program due to suspucious about nuclear weapon development. ${ }^{6}$ ) Artinya bahwa Amerika Serikat memberikan sejumlah sanksi kepada Iran karena tingginya ketidakpercayaan terhadap Iran atas perkembangan program nuklir mereka yang dianggap mencurigakan. Berdasarkan Perjanjian Nonproliferasi Nuklir, Iran tidak memiliki kewenangan untuk mengembangkan senjata nuklir karena tidak termasuk ke dalam kelompok Nuclear Weapons States.

6 ) Mahdieh Aghazadeh, "International Sanctions And Their Impact On Iran's Economy", International Journal of Economy And Finance Studies, Volume 6, No.2, 2014 hal. 25 .
Teddy Nurcahyawan \& Stevanus Rivaldo Ekstradisi Meng Wanshou dalam Prespektif...

Sanksi yang diberikan oleh Pemerintah Amerika Serikat tersebut di antaranya larangan pembelian minyak dari Iran dan larangan untuk melakukan transaksi dengan lebih dari 300 entitas perusahaan Iran. $^{7 \text { ) }}$ Adapun sanksi tersebut diperbaharui pada awal November tahun 2018. ${ }^{8)}$

Lebih jauh lagi, Meng Wanzhou diduga melakukan transaksi perdagangan dengan Iran melalui perusahaan Skycom yang diduga pula merupakan anak perusahaan Huawei. ${ }^{9)}$ Tindakan ini dianggap oleh Pemerintah Amerika Serikat sebagai bentuk pelanggaran atas sanksi Pemerintah Amerika Serikat terhadap Iran. Pemerintah Amerika Serikat sendiri telah meminta pula kepada Kanada agar Meng Wanzhou segera diekstradisi

7) Kompas, "Iran Tetap Bisa Jual Minyak", Kompas, 7 November 2018, hal. 8.

${ }^{8}$ VOA Indonesia, "AS Mulai Berlakukan Sanksi Terhadap Iran", http://www.voaindonesia.com/a/as-mulaiberlakukan-sanksi-terhadapiran/4515389.html diakses pada tanggal 21 Januari 2019 pukul 15.10.

9) John Azpiri "Huawei CFO Meng Wanzhou Granted Bail, Will Live In Vancouver Under Electronic Survaillance, https://globalnews.ca/news/4749540/mengwanzhou-huawei-bail-hearing-day-3/ diakses pada tanggal 18 Desember 2018 pukul 20.36. 


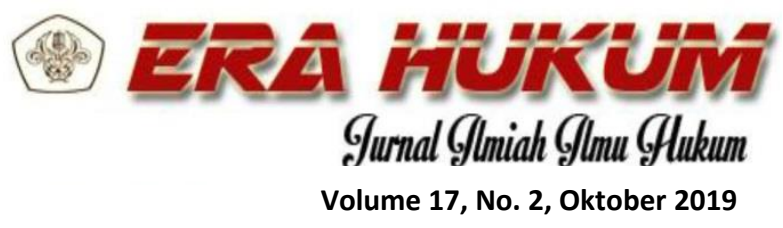

ke Amerika Serikat. ${ }^{10}$ ) Dalam dokumen yang dikeluarkan oleh Kementerian Hukum Kanada yang ditujukan kepada Kejaksaan Agung Kanada, mengatakan bahwa tindakan yang dilakukan oleh Meng Wanzhou tergolong dalam suatu kejahatan frauding. Frauding sendiri termasuk ke dalam jenis kejahatan yang termasuk ke dalam Perjanjian Ekstradisi Antara Kanada dan Amerika Serikat.

Sedangkan di sisi lain, Pemerintah Tiongkok mengecam keras tindakan Pemerintah Kanada atas warganya. Pemerintah Tiongkok, melalui Kementerian Luar Negeri Tiongkok, telah meminta kepada Pemerintah Kanada untuk dapat melepaskan Meng Wanzhou. Mereka juga telah meminta penjelasan kepada Pemerintah Kanada dan Pemerintah Amerika Serikat mengenai penangkapan warganya tersebut. $^{11)}$

10) Daisuke Wakabayashi dan Alan Rapeport, "Huawei CFO Is Arrested In Canada For Estradition To The U.S.", https://www.nytimes.com/2018/12/05/business/ huawei-cfo-arrest-canada-extradition.html diakses pada tanggal 18 Desember 2018 pukul 20.50 .

11) Lily Kuo, "China Demands Release of Huawei Executive Arrested In Canada",
Teddy Nurcahyawan \& Stevanus Rivaldo Ekstradisi Meng Wanshou dalam Prespektif...

Peneliti memandang bahwa kasus ini sangat menarik. Selama ini ekstradisi dikenal hanya melibatkan dua negara saja, antara negara peminta dan negara diminta, namun kali ini ada keterlibatan negara ke tiga. Keterlibatan negara ke tiga dalam proses ekstradisi menjadi persoalan yang pelik mengingat tentu saja suatu negara tidak mau ada warga negaranya yang ditangkap oleh negara lain atas permintaan negara yang lain pula. $^{12)}$

\section{B. Rumusan Masalah}

Dalam penelitian ini, Peneliti menggunakan rumusan masalah sebagai berikut:

1. Apakah Pemerintah Amerika Serikat dapat meminta Pemerintah Kanada mengekstradisi Meng Wanzhou sesuai dengan hukum internasional?

2. Bagaimana mekanisme permintaan ekstradisi Meng Wanzhou Pemerintah Amerika

http://www.theguardian.com/technology/2018/ dec/05/meng-wanzhou-huawei-cfo-arrestedvancouver diakses pada tanggal 21 Januari 2019 pukul 14.45.

${ }^{12)}$ Romli Artasasmita, Loc. Cit., hal. 11. 
Serikat kepada Pemerintah Kanada?

\section{Metode Penelitian}

Dalam penelitian ini, secara umum Peneliti menggunakan metode penelitian normatif atau disebut juga penelitian dalam perspektif doktrinal $^{13)}$. Penelitian hukum normatif berpijak pada hukum yang berlaku pada masa sekarang. Peneliti melakukan penelitian dengan mengumpulkan, membaca, serta menganalisa berbagai sumber bahan, baik yang bahan bersifat hukum maupun bahan yang bersifat nonhukum dan memiliki relevansi erat dengan permasalahan yang sedang diteliti. Pengumpulan bahanbahan tersebut dilakukan dengan cara studi kepustakaan, yaitu mencari, membaca, serta menganalisa sumber bahan-bahan tersebut melalui media daring ataupun media-media lain yang bersifat konvensional.

13 ) Ahmad Zuhdi Muhdlor, "Perkembangan Metodologi Penelitian”. Jurnal Hukum dan Peradilan, Volume 1, Nomor 2, Tahun 2012, hal. 196.
Secara lebih spesifik, Peneliti dalam penelitian ini menggunakan metode IRAC. Metode ini telah dikenal luas sebagai suatu metode yang digunakan berbagai praktisi maupun akademisi di seluruh dunia dalam memecahkan masalah-masalah hukum. Metode ini dapat digunakan secara praktik di lapangan maupun dalam berbagai penelitianpenelitian ilmiah. Hal ini pula dikemukakan oleh Tracy Turner. Ia mengatakan existing scholarship on the proper organization of e legal analysis is dominated by the IRAC paradigm and its numerous spin-offs ${ }^{14}$ ). Turner ini mengatakan bahwa penggunaan metode IRAC beserta berbagai variasinya telah secara sering digunakan oleh para akademisi di lingkungan lembaga-lembaga hukum.

\section{Pembahasan}

\section{A. Lembaga Ekstradisi}

1. Sebagai Bagian dari Hukum Internasional

\footnotetext{
14) Tracy Turner, "Flexible IRAC: A Best Pratices Guide", Legal Writing Journal, Volume 20, 2015, hal. 233.
} 
Teddy Nurcahyawan \& Stevanus Rivaldo

Dalam berbagai doktrin, para ahli hukum sepakat bahwa salah satu unsur penting dari definisi hukum internasional adalah 'mengatur hubungan antarnegara'. Dengan demikian, tidaklah mungkin jika ekstradisi hanya melibatkan satu negara saja. Dengan demikian, secara singkat dapat disimpulkan bahwa ekstradisi merupakan bagian dari hukum internasional karena adanya unsur 'mengatur hubungan antarnegara'. Dalam hal ini ekstradisi mengatur bagaimana penyerahan seseorang yang melakukan kejahatan atau diduga melakukan kejahatan diserahkan dari satu negara ke negara lainnya yang memiliki yurisdiksi atas kejahatan tersebut.

2. Sebagai Bagian dari Perjanjian Internasional

Perjanjian internasional merupakan salah satu sumber hukum internasional, hal ini tercantum dalam Pasal 38 ayat (1) Statuta Mahkamah
Internasional. Jika ditinjau dari segi kaedah hukum yang lahir dari perjanjian, perjanjian internasional terbagi dalam dua macam, yaitu treaty contract dan law making treaty. Treaty contract berarti perjanjian yang dibuat hanya mengikat para pihak yang mengikatkan diri saja, contoh Perjanjian

Dwikewarganegaraan Antara Indonesia dan Tiongkok tahun 1955, sementara konsep law making treaty berarti perjanjian yang melahirkan kaedah hukum yang dapat berlaku secara umum, 15 ) contohnya adalah Konvensi Wina tahun 1961 tentang Hubungan Diplomatik.

Dalam membentuk perjanjian ekstradisi, negaranegara akan membentuknya dalam sebuah perjanjian internasional. Alasannya adalah perjanjian internasional dianggap memiliki jaminan kepastian hukum yang

15) I Made Pasek Diantha, Hukum Perjanjian Internasional, (Denpasar: Fakultas Hukum Universitas Udayana, 2017). hal. 19. 
tinggi. ${ }^{16)}$ Pada praktiknya di dunia internasional, perjanjian ekstradisi biasanya diwujudkan dalam bentuk treaty contract yang bersifat bilateral. Perjanjian ekstradisi bersifat treaty contract mengingat perjanjian ekstradisi hanya mengikat negara-negara yang mengikatkan diri pada perjanjian tersebut saja, serta tidak melahirkan suatu kaedah hukum yang berlaku secara umum di dunia internasional.

$$
\text { Pada kasus yang }
$$
menjadi objek penelitian ini, perjanjian ekstradisi yang digunakan adalah perjanjian ekstradisi antara Amerika Serikat dengan Kanada (Extradition Treaty Between United States of America and Canada). Dalam perjanjian tersebut para pihak yang mengikatkan diri hanyalah kedua negara yang membuat perjanjian, tidak ada pihak lain yang ikut terlibat sebagai

16) I Wayan Parthiana, Ekstradisi Dalam Hukum Perjanjian Internasional Modern, (Bandung: Yrama Widya, 2009). hal. 76. pihak ke tiga dalam perjanjian tersebut. Dengan demikian, dapat dikatakan bahwa perjanjian ekstradisi tersebut merupakan sebuah perjanjian bilateral yang bersifat treaty contract.

\section{B. Keluarnya Amerika Serikat} dari Joint Comprehensive Plan of Action (JCPOA)

Amerika Serikat keluar dari JCPOA dengan alasan bahwa Iran gagal berlaku jujur terhadap program nuklirnya, mendukung kelompok terorisme serta dianggap berlaku dengan sikap yang 'bermusuhan' di Timur Tengah. Dalam pandangan Peneliti, ada faktor lain yang menjadi alasan keluarnya Amerika Serikat dari JCPOA. Faktor tersebut adalah mengenai kebijakan domestik Pemerintah Amerika Serikat di bawah pemerintahan Presiden Donald Trump. Dalam pemerintahannya, Presiden Donald Trump sangat mengedepankan kebijakan proteksionisme. 17 ) Hal ini

\footnotetext{
17 ) Proteksionisme merupakan salah satu bentuk kebijakan luar negeri dalam sektor
} 
Teddy Nurcahyawan \& Stevanus Rivaldo

ditandai dengan keluarnya

Amerika Serikat dari Perjanjian

Kemitraan Trans-Pasifik (Trans-

Pacific Partnership) sehari

setelah pelantikan dirinya sebagai

Presiden Amerika Serikat,

kemudian adanya renegosiasi

Perjanjian Perdagangan Bebas

Amerika Utara (North America

Free Trade Agreement/NAFTA)

hingga adanya peningkatan tarif

berbagai komoditi ekspor seperti

besi dan aluminium. Kebijakan

proteksionisme ini bertentangan

dengan kebijakan Pemerintah

Amerika sebelum dipimpin oleh

Donald Trump yang cenderung

lebih liberal.

With the protectionism

policy, Trump administration wants to renegotiate what it deems fairer and more balanced almost every single international agreement that his predecessor has been made to promote the creation of United States jobs and

ekonomi dan perdagangan dari suatu negara yang lebih mengdepankan kepentingan dalam negerinya. Kebijakan ini ditandai dengan pemberlakuan tarif dan bea masuk berbagai komoditi yang ketat, pembatasan eskpor sektor barang dan jasa, serta peningkatan subsidi terhadap barang-barang dan jasa produksi dalam negeri. prosperity. ${ }^{18}$ ) Artinya, dengan model kebijakan proteksionisme tersebut, Amerika Serikat akan meninjau ulang berbagai kesepakatan internasional yang telah mereka ikuti untuk kemudian dinilai apakah masih dianggap menguntungkan atau adil bagi Amerika Serikat atau tidak demi terciptanya lapangan kerja serta kesejahteraan domestik Amerika Serikat.. Keluarnya Amerika Serikat dari JCPOA merupakan salah satu indikasi bahwa Amerika Serikat menilai perjanjian tersebut tidak lagi menguntungkan.

Bergabungnya Amerika Serikat di JCPOA akan membuat sanksi yang dijatuhkan Amerika Serikat kepada Iran tidak lagi berlaku. Hal ini akan membuat Iran mampu untuk melakukan transaksi perdagangan dengan Amerika Serikat. Namun hal itu dianggap tidak menguntungkan Amerika Serikat karena dengan adanya transaksi perdagangan

18) Aaron Ettinger, "Trump's National Security Strategy: 'America First' Meets the Establishment", Canada's Journal of Global Policy Analysis, September, 2018, hal. 3. 
dengan Iran maka, uang Amerika Serikat akan masuk ke Iran. Kemudian Amerika Serikat menganggap bahwa Iran menggunakan uang hasil perdagangan tersebut untuk mengembangkan teknologi serta membiayai kelompok-kelompok terorisme. Anggapan Amerika Serikat inilah kemudian yang menurut perspektif Peneliti menjadi penyebab lain mundurnya Amerika Serikat dari JCPOA.

Sikap Amerika Serikat yang memilih untuk keluar dari JCPOA pada tahun 2018 membuat Amerika Serikat kembali menerapkan sanksi kepada Iran. Pada bagian Kata Pengantar (Preface) paragraf ke empat JCPOA menyatakan:

"The JCPOA will produce the comprehensive lifting of all UN Security Council sanctions as well as multilateral and national sanctions related to Iran's nuclear programme, including steps on access in areas of trade, technology, finance, and energy."
Artinya adalah JCPOA akan menghasilkan suatu pencabutan sanksi secara komprehensif yang telah diberikan oleh DK PBB serta berbagai sanksi yang bersifat multilateral ataupun nasional terhadap program nuklir Iran. JCPOA juga akan membuat Iran kembali memiliki akses ke aktivitas perdagangan, teknologi, finansial serta energi dengan dunia internasional.

$$
\text { Pada }
$$

klausul

kesepakatan tersebut, selama suatu negara masih menjadi bagian dari JCPOA, maka negara tersebut tidak bisa lagi menerapkan sanksi kepada Iran. Dengan mundurnya Amerika Serikat dari kesepakatan tersebut, tentu saja akan menghasilkan konsekuensi bahwa Amerika Serikat dapat kembali menerapkan sanksi kepada Iran.

\section{Penegakkan Kedaulatan Negara}

Pada dasarnya, menurut Boer Mauna konsep kedaulatan negara memberikan wewenang kepada suatu negara untuk menegakkan hukum yang berlaku di 
wilayahnya. 19 ) Artinya bahwa negara memiliki kewenangan untuk mengatur serta menegakkan hukum terhadap orang maupun benda yang berada di wilayahnya tanpa adanya intervensi negara lain. Hal ini sejalan dengan prinsip non intervensi sebagaimana yang tertuang pada Pasal 2 ayat (1) Piagam Perserikatan BangsaBangsa (Piagam PBB) menyatakan: "The Organization is based on the principle of the sovereign equality off all its members". Artinya adalah bahwa Perserikatan Bangsa-Bangsa dibentuk dengan berlandaskan pada asas persamaan kedaulatan yang melekat pada anggotanya. Dengan kata lain dapat dikatakan bahwa ayat tersebut menjamin terlaksananya kedaulatan negara anggota PBB untuk bebas dari segala intervensi dari pihak luar.

Penangkapan Meng Wanzhou merupakan salah satu bentuk penegakkan kedaulatan negara Kanada. Kanada memiliki perjanjian ekstradisi dengan

19 ) Boer Mauna, Hukum Internasional: Pengertian Peranan Dan Fungsi Dalam Era Dinamika Global, Edisi Ke-2, (Bandung: Alumni, 2005)., hal. 24.
Amerika Serikat yang membuat Amerika Serikat bisa meminta siapa saja yang diduga melanggar hukum Amerika Serikat untuk ditangkap dan diekstradisi. Pelaksanaan kedaulatan negara tersebut tentu saja harus bebas dari intervensi negara mana pun, termasuk juga harus bebas dari intervensi Tiongkok, sebagai negara asal Meng Wanzhou. Tiongkok harus menghormati Kanada dalam menjalankan kedaulatan negaranya.

Hal serupa juga berlaku bagi Amerika Serikat. Permintaan Amerika Serikat kepada Pemerintah Kanada untuk mengekstradisi Men Wanzhou juga merupakan salah satu bentuk penegakkan kedaulatan negara Amerika Serikat. Meng Wanzhou diduga telah melakukan frauding terhadap salah satu lembaga keuangan Amerika Serikat, sehingga Meng Wanzhou dianggap telah melakukan tindak kejahatan terhadap entitas milik Amerika Serikat. Dengan demikian, permintaan Amerika Serikat untuk mengekstradisi Meng Wanzhou 
Teddy Nurcahyawan \& Stevanus Rivaldo

Volume 17, No. 2, Oktober 2019

Ekstradisi Meng Wanshou dalam Prespektif..

adalah suatu bentuk penegakkan hukum Amerika Serikat, dan Tiongkok harus pula menghormati hal ini.

Tiongkok dalam kasus ini juga memiliki hak untuk menjalankan kedaulatan negaranya. Berdasarkan prinsip nasionalitas aktif, setiap negara memiliki kewajiban untuk melindungi warga negaranya yang sedang berada di luar negeri. ${ }^{20)}$ Meng Wanzhou sebagai warga negara Tiongkok memiliki hak untuk mendapat perlindungan dari negara asalnya. Prinsip ini membuat Tiongkok memiliki kewajiban untuk berusaha melindungi Meng Wanzhou yang sedang memiliki permasalahan hukum di Kanada maupun Amerika Serikat. Kanada dan Amerika Serikat dalam hal ini juga harus menghormati Tiongkok yang sedang melakukan penegakkan kedaulatan negaranya melalui prinsip nasionalitas aktif.

Uraian di atas dapat kita simpulkan bahwa baik Amerika Serikat, Kanada serta Tiongkok

20) Fred B. Rothman, International Criminal Law, (New York: Sweet and Maxwell, 1965). hal. 61.

memiliki hak untuk menegakkan kedaulatan negaranya masingmasing. Penegakkan tersebut hendaknya pula dilakukan sesuai dengan koridor hukum serta jalurjalur diplomasi yang ada sehingga tidak ada pihak yang dirugikan atau dilanggar haknya serta demi terjaganya penegakkan hukum dan ketertiban dunia.

\section{Unsur-Unsur dalam Ekstradisi}

Berdasarkan definisi ekstradisi, maka menurut I Wayan Parthiana diperoleh unsur-unsur ekstradisi sebagai berikut: ${ }^{21)}$

1. Unsur subyek hukum

Unsur ini berisi subyek-subyek hukum apa saja yang terlibat dalam ekstradisi. Subyek hukum dalam ekstradisi ada dua, yaitu:

a. Unsur negara peminta (the requesting state/states) Unsur negara peminta merupakan negara yang memiliki kepentingan untuk mengadili pelaku kejahatan yang akan

21 ) I Wayan Parthiana, Ekstradisi Dalam Hukum Internasional Modern, Op. Cit., hal. 39-43 
Teddy Nurcahyawan \& Stevanus Rivaldo Ekstradisi Meng Wanshou dalam Prespektif..

diekstradisi. Dalam

suatu kasus ekstradisi, negara peminta bisa berjumlah lebih dari dua, 22 ) karena dimungkinkan seorang pelaku melakukan suatu kejahatan di dua negara yang berbeda sehingga akan muncul dua negara yang memiliki yurisdiksi untuk mengadili pelaku.

Dalam kasus yang menjadi obyek penelitian ini, yang bertindak sebagai negara peminta adalah Amerika Serikat.

Terlihat jelas bahwa Amerika Serikat pula yang meminta Pemerintah Kanada untuk menangkap Meng Wanzhou untuk diekstradisi. Amerika Serikat dalam hal ini memiliki kepentingan untuk mengadili Meng Wanzhou karena ia

22) Ibid., hal. 39. telah melakukan suatu tindak kejahatan yang merugikan suatu entitas finansial di Amerika Serikat.

Tiongkok pun dapat memosisikan dirinya sebagai negara peminta. Ia memiliki yurisdiksi untuk mengadili Meng Wanzhou berdasarkan dari prinsip nasionalitas aktif, yaitu prinsip dimana negara memiliki kewenangan untuk mengadili warga negaranya yang melakukan kejahatan di luar negeri berdasarkan hukum nasionalnya. ${ }^{23}$ ) Namun demikian, jika Tiongkok ingin memosisikan dirinya sebagai negara peminta ke dua, ia harus mengajukan permohonan secara resmi kepada

23 ) Ilias Bantekas dan Susan Nash, International Criminal Law, ( :Cavendish Publishing, 2003). hal. 151. 
Pemerintah Kanada

untuk mengekstradisi

Meng Wanzhou. Hingga

penelitian ini dibuat,

Tiongkok masih belum

menunjukan

keinginannya untuk

memosisikan diri

mereka secara resmi

sebagai negara peminta

ke dua di samping

Amerika Serikat.

a. Unsur negara diminta

(the requested state)

Negara dalam

unsur ini adalah

negara yang dimintai

untuk mengekstradisi

pelaku kejahatan

yang sedang berada

di wilayah negaranya

oleh negara peminta.

Negara diminta ini

boleh jadi memiliki

yurisdiksi terhadap

kejahatan yang

dilakukan oleh

pelaku atau tidak

memiliki yurisdiksi

sama sekali. Jumlah

negara diminta tentu hanya berjumlah satu

negara saja.

Kanada berada

dalam posisi sebagai

negara diminta dalam

penelitian kali ini.

Mereka yang

menangkap dan

menahan Meng

Wanzhou atas

permintaan Amerika

Serikat berdasarkan

perjanjian ekstradisi

yang ada di antara

kedua negara

tersebut. Dalam hal

ini Kanada tidak

memiliki yurisdiksi

untuk mengadili

kejahatan yang

dituduhkan kepada

Meng Wanzhou,

mengingat Amerika

Serikat yang meminta

Meng Wanzhou

untuk diadili di

negaranya atas

tuduhan kejahatan

yang ia lakukan.

2. Unsur obyek hukum (the requested person) 
Obyek hukum dalam ekstradisi adalah orang ataupun individu yang diduga melakukan tindak kejahatan yang diminta terhadapnya dilakukan ekstradisi. Status orang yang menjadi obyek hukum ekstradisi dapat berupa tersangka, tertuduh, terdakwa, ataupun terhukum. Sangat jelas bahwa obyek hukum dalam kasus ini adalah Meng Wanzhou, chief financial officer dari Huawei.

3. Unsur tata cara atau prosedur

Dalam unsur ini segala proses yang dilakukan dalam upaya ekstradisi, mulai dari permintaan, pemberitahuan persetujuan atau penolakan ekstradisi hingga tata cara penyerahan pelaku kejahatan dilakukan secara formal. ${ }^{24)}$ Secara umum, ekstradisi harus dilakukan dengan usahausaha diplomatik antarnegara, jika dilakukan di luar usaha diplomatik antarnegara maka dapat dikatakan bahwa hal tersebut bukan merupakan suatu upaya ekstradisi.

Amerika Serikat maupun Tiongkok serta Kanada dalam kasus ini melakukan berbagai upayanya melalui jalurjalur diplomatik yang ada di antara negara-negara tersebut. Ini sesuai dengan ketentuan dari Pasal 9 ayat (1) Perjanjian Ekstradisi Antara Amerika Serikat dengan Kanada yang berbunyi "The request of extradition shall be made through diplomatic channel". Dapat diartikan bahwa permintaan esktardisi antara kedua

\footnotetext{
${ }^{24)}$ I Wayan Parthiana, Op. Cit., hal. 40.
} 
Teddy Nurcahyawan \& Stevanus Rivaldo Ekstradisi Meng Wanshou dalam Prespektif...

negara harus dilakukan

melalui jalur-jalur

diplomatik.

Ketentuan ini pun dilaksanakan oleh kedua belah pihak. Amerika Serikat misalnya, telah melakukan permintaan ekstradisi secara formal kepada Kanada dan Kanada telah secara resmi mengabulkan hal tersebut, kemudian Tiongkok yang telah mengeluarkan protes terhadap penangkapan tersebut melalui pernyataan diplomatik yang dikeluarkan oleh Kedutaan Besar Tiongkok di Kanada. Sebelumnya pula, Amerika Serikat telah melalui jalur diplomatik yang formal untuk mengajukan perpanjangan penahanan Meng Wanzhou oleh Pemerintah Kanada.

Dengan demikian kita dapat melihat bahwa dalam kasus ini, segala upaya yang dilakukan oleh negara-negara yang terlibat dalam ekstradisi dilakukan melalui jalurjalur diplomatik yang formal. Hal tersebut membuat unsur tata cara dalam ekstradisi dapat dikatakan terpenuhi.

4. Unsur maksud dan tujuan Unsur ini berisi maksud dan tujuan dari negara peminta untuk mengekstradisi pelaku kejahatan kepada negara diminta. Maksud dan tujuan itu dapat berupa untuk diadili oleh negara diminta atau untuk menghabiskan sisa hukuman yang telah dijatuhkan kepada pelaku di negara diminta. ${ }^{25)}$

Amerika Serikat mengajukan permohonan ekstradisi atas Meng Waznhou kepada Pemerintah Kanada dengan maksud dan tujuan untuk memeriksa serta mengadili ia atas

\footnotetext{
25) Ibid., hal. 43.
} 
Teddy Nurcahyawan \& Stevanus Rivaldo

Volume 17, No. 2, Oktober 2019

tuduhan kejahatan yang

hukum tersebut dapat

dilakukan olehnya. Jelas

maksud dan tujuan

berupa perjanjian

ekstradisi antarnegara

Amerika Serikat meminta

ekstradisi atas Meng

Wanzhou bukanlah

supaya ia menghabiskan

sisa hukuman di Amerika

Serikat mengingat Meng

Wanzhou belum pernah

dijatuhkan putusan pidana

oleh pengadilan di

Amerika Serikat,

melainkan untuk diadili di

Amerika Serikat.

Melihat hal di atas, dapat disimpulkan pula bahwa unsur maksud dan tujuan telah terpenuhi.

Maksud dan tujuan

Amerika Serikat meminta ekstradisi Meng Wanzhou adalah untuk mengadilinya.

E. Pemenuhan

Asas-Asas

5. Unsur dasar atau landasan hukum

\section{Ekstradisi}

1. Asas

kekhususan

Segala unsur di atas tersebut haruslah

berdasarkan hukum yang jelas supaya legalitasnya juga terjamin. Dasar (principle of specialty)

Secara umum, Siswanto Sunarso mengartikan asas ini 
bahwa pelaku kejahatan yang diekstradisi hanya dapat diadili atas dasar kejahatan yang dijadikan sebagai alasan untuk dilakukannya

ekstradisi. 27 ) Dalam konteks penelitian ini, Meng Wanzhou dituduh melakukan kejahatan yang tergolong dalam kategori frauding oleh Amerika Serikat.

Amerika Serikat hanya boleh mengadili Meng Wanzhou atas kejahatan yang menjadi alasan permintaan ekstradisi tersebut.

Peneliti menyatakan bahwa asas ini telah terpenuhi. Pemenuhan tersebut dibuktikan dengan adanya ketentuan mengenai syarat apa saja agar suatu kejahatan dapat dijadikan dasar ekstradisi. Kejahatan yang dituduhkan kepada Meng Wanzhou adalah

${ }^{27)}$ Siswanto Sunarso, Op. Cit., hal. 107. frauding. Dalam Pasal 1 ayat 1 Protokol Perubahan Perjanjian Ekstradisi Antara Amerika Serikat dan Kanada berbunyi: Extradition shall be granted for conduct which constitute offense punishable by the laws of both Contracting Party by imprisonment or other form of detention for a term exceeding one year or any greater punishment. Artinya ekstradisi dapat dilakukan jika kejahatan yang menjadi dasar untuk melakukan ekstradisi diancam oleh pidana penjara lebih dari satu tahun.

Frauding dalam hukum pindana Amerika Serikat dinacam dengan pidana penjara maksimal 10 tahun. Dengan demikian kejahatan yang dilakukan Meng Wanzhou masuk ke 
dalam kategori kejahatan

yang bisa diekstradisi.

Amerika

Serikat

kemudian

harus

memeriksa dan mengadili

Meng Wanzhou hanya

dengan dasar kejahatan

frauding tersebut.

2. Asas tidak mengekstradisi warga negaranya

Dalam asas ini, negara diminta dapat menolak melakukan ekstradisi jika pelaku kejahatan yang dimintakan untuk diekstradisi adalah warga negaranya. Asas ini pernah menjadi alasan Pemerintah Arab Saudi untuk mengabulkan permintaan ekstradisi Turki terhadap 18 orang pelaku pembunuhan Jamal Kashoggi. Pemerintah Arab Saudi melalui Menteri Luar Negeri Arab Saudi Adel Al-Jubeir mengatakan bahwa Pemerintah Arab Saudi tegas menolak permohonan Turki untuk mengekstradisi seluruh pelaku pembunuhan Jamal Kashoggi. Ia menambahkan bahwa Pemerintah Arab Saudi memiliki yurisdiksi untuk menyelidiki dan menuntut pelaku yang keseluruhannya adalah warga negara Arab Saudi

Meng Wanzhou yang menjadi obyek di kasus ekstradisi ini merupakan warga negara Tiongkok, sedangkan yang bertindak sebagai negara diminta adalah Kanada. Hal ini membuat salah satu alasan Kanada untuk tidak mengekstradisi Meng Wanzhou menjadi hilang.

3. Asas tidak mengekstradisi pelaku kejahatan politik

Artinya bahwa seseorang tidak dapat diekstradisi dengan dasar bahwa ia telah melakukan 
suatu kejahatan politik. ${ }^{28)}$

Dalam Pasal 4 ayat (1) angka 3 Perjanjian

Ekstradisi

Antara

Amerika Serikat dan

Kanada

tertulis:

"Extradition shall not be granted when the offense of which extradition is requested is of political character". Artinya ekstradisi tidak dapat dilakukan apabila objek dari ekstradisi adalah seorang figur politik.

Salah satu kasus yang bisa menjadi rujukan adalah kasus Carles Puigdemont. Ia merupakan seorang pemimpin separatis Catalan yang ke Jerman. Spanyol kemudian mengajukan permohonan ekstradisi kepada Jerman atas tuduhan Puigdemont melakukan pemberontakan. Namun, Jerman melalui putusan pengadilan menolak permohonan ekstradisi tersebut dengan alasan bahwa dasar permohonan ekstradisi yang diajukan Spanyol, yaitu pemberontakan, tidak dapat diterima.

Meng Wanzhou yang menjadi obyek ekstradisi pada kasus kali ini bukanlah seorang figur politik. Ia adalah seorang chief financial officer dari Huawei perusahaan Tiongkok yang bergerak di bidang teknologi informasi. Kejahatan yang dituduhkan kepada Meng Wanzhou pun oleh Amerika Serikat adalah frauding yang tidak memiliki relevansi dengan suatu kejahatan politik.

4. Asas daluwarsa

Dalam Perjanjian Ekstradisi Antara Amerika Serikat dan Kanada, perihal daluwarsa diatur dalam Pasal 4 ayat 1 angka III 
yang berbunyi

"Extradition shall not be granted when the prosecution of the offense has become barred lapse of time according to laws of the requesting states." Artinya bahwa ekstradisi tidak dapat dilakukan jika waktu penuntutan telah melawati masa daluwarsa berdasarkan hukum dari negara yang diminta. Di Amerika Serikat, masa daluwarsa untuk kasus frauding terhadap lembaga finansial berdasarkan United States Criminal Code title 18 section 1344 (18 U.S.C. 1344) adalah 10 tahun sejak kejahatan tersebut dilakukan.

Dugaan kejahatan yang dilakukan oleh Meng Wanzhou sendiri dilakukan pada tahun 2013 sehingga masa daluwarsa kasus tersebut adalah 2023, sedangkan penangkapan Meng
Wanzhou

oleh

Pemerintah Kanada terjadi pada tahun 2018. Dengan demikian dapat disimpulkan bahwa kasus yang dituduhkan kepada Meng Wanzhou belum memasuki masa daluwarsa sehingga masih bisa untuk dilakukan penuntutan dan diadili.

5. Asas kejahatan ganda

Asas ini secara singkat berarti suatu tindakan dikategorikan sebagai suatu tindak kejahatan jika oleh kedua negara yang melakukan perjanjian ekstradisi disepakati demikian. Hal ini sering menjadi polemik dalam ranah hukum ekstradisi. Salah satunya terjadi antara Singapura dan Indonesia mengenai definisi korupsi. Di Indonesia, korupsi harus memenuhi unsur adanya kerugian negara, sedangkan di Singapura korupsi 
didefinisikan dalam

Singapore's Prevention of

Corruption Act sebagai suatu 'bribe return for favor' yang secara sederhana diartikan sebagai 'penyuapan'.

Adanya perbedaan persepsi mengenai definisi perbuatan korupsi antara Singapura dan Indonesia membuat asas kejahatan ganda tidak terpenuhi, sehingga proses ekstradisi pelaku korupsi antara Singapura dan Indonesia tidak dapat terlaksana. Padahal, ada banyak tersangka korupsi di Indonesia yang kabur, namun Pemerintah Indonesia tidak dapat berbuat banyak mengingat Singapura selalu menolak permintaan ekstradisi Indonesia terhadap para pelaku tersebut dengan alasan adanya perbedaan persepsi mengenai definisi perbuatan korupsi.

Perjanjian Ekstradisi Antara Amerika Serikat dan Kanada asas kejahatan ganda dituangkan dengan sistem tanpa daftar (eliminative system), yaitu ketika suatu kejahatan yang dapat dijadikan alasan ekstradisi ditentukan dengan ancaman hukuman terhadap kejahatan tersebut. Ini terlihat dalam Pasal 1 ayat (1) Protokol Perubahan Perjanjian Ekstradisi Antara Amerika Serikat dan Kanada yang berbunyi: Extradition shall be granted for conduct which constitute offense punishable by the laws of both Contracting Party by imprisonment or other form of detention for a term exceeding one year or any greater punishment. Artinya seorang pelaku kejahatan 
harus diekstradisi

berdasarkan perjanjian ini atas dasar kejahatan yang dijadikan dasar ekstradisi diancam dengan pidana minimal satu tahun oleh kedua negara (Amerika Serikat dan Kanada).

Dalam Perjanjian Ekstradisi Antara Amerika Serikat dan Kanada awalnya mengatur kejahatan yang dapat didasarkan sebagai alasan ekstradisi dalam suatu daftar resmi (Schedule), namun dalam protokol perubahan perjanjian tersebut, daftar kejahatan yang bisa dijadikan ekstradisi itu dihapus. Ini tertuang dalam Pasal 2 Protokol Tambahan Perjanjian Ekstradisi Antara Amerika Serikat dan Kanada yang berbunyi: The SCHEDULE to the Extradition Treaty, as amanded, is deleted.
Amerika Serikat menuntut Meng Wanzhou atas kejahatan frauding. Dalam United States Criminal Code title 18 section 1344 (18 U.S.C. 1344) yang mengatur mengenai Bank Fraud, kejahatan yang dituntut kepada Meng Wanzhou oleh Amerika Serikat diancam pidana penjara selama maksimal 10 tahun. Ancaman pidana ini lebih dari satu tahun sehingga Peneliti dapat menyatakan bahwa asas kejahatan ganda dalam kasus yang diteliti ini terpenuhi.

6. Asas yurisdiksi

Sebuah negara dapat meminta seseorang untuk diekstradisi ke negaranya ketika negara tersebut memiliki yurisdiksi untuk mengadili pelaku kejahatan yang menjadi obyek ekstradisi tersebut. Dalam hal ini Amerika Serikat dapat dikatakan 
memiliki yurisdiksi untuk mengadili Meng

Wanzhou. Yurisdiksi ini diperoleh dengan dasar adanya Perjanjian

Ekstradisi

Antara

Amerika Serikat dan

Kanada. Perjanjian ini kemudian dijadikan sebagai dasar semua proses ekstradisi yang dilakukan antara Amerika Serikat dan Kanada

Hal ini dibuktikan dengan adanya surat permintaan perpanjangan penahanan Meng

Wanzhou oleh

Kejaksaaan New York Timur dengan kode surat AAS:SME/JN/DKK tertanggal 3 Desember 2018. Dalam surat tersebut berisikan permintaan resmi dari Kejaksaan New York Timur kepada Pemerintah Kanada untuk memperpanjang masa penahanan Meng Wanzhou di Kanada serta berbagai hal yang menjadi dasar permintaan tersebut. Adanya surat resmi dari Kejaksaan New York Timur ini menjadi bukti lain yang menyatakan bahwa Amerika Serikat memiliki yurisdiksi atas kejahatan yang dilakukan oleh Meng Wanzhou.

7. Asas ne bis in idem

Asas ini membuat seseorang tidak boleh diadili dua kali atas kejahatan yang sama. Contohnya ada seseorang dari negara A pergi ke negara B. Kemudian orang tersebut melakukan pembunuhan di negara $B$. Negara B mengadili orang tersebut atas kejahatan pembunuhan itu dan akhirnya dijatuhi hukuman penjara. Setelah hukuman pidana itu dijalani, negara A meminta negara $\mathrm{B}$ untuk mengekstradisi orang tersebut dengan dasar 
pembunuhan yang ia

lakukan di negara $B$.

Negara meminta

ekstradisi dengan dasar

asas nasionalitas aktif

yang berarti hukum

nasionalnya tetap berlaku

terhadap warga negaranya

di mana pun ia berada.

Karena orang tersebut

sudah diadili dan

dihukum maka negara $\mathrm{A}$

tidak dapat lagi mengadili

dan menghukum orang

tersebut karena kejahatan

yang dilakukannya telah

diadili dan ia telah

menjalani masa hukuman.

Dengan demikian tidak

ada kewajiban bagi

negara B untuk

mengekstradisi si pelaku.

Inilah contoh dari

penerapan asas ne bis in idem.

Kasus

yang

dituduhkan kepada Meng

Wanzhou belum pernah

diadili oleh Amerika

Serikat, sehingga dapat

dikatakan bahwa asas ini terpenuhi dan Amerika

Serikat dapat mengadili

Meng Wanzhou atas

kejahatan yang

dituduhkan kepadanya

tersebut.

\section{F. Aspek Kewarganegaraan}

\section{Meng Wanzhou}

Proses ekstradisi yang terjadi pada umumnya hanya melibatkan dua negara saja, yaitu negara diminta dan negara peminta. Menjadi suatu polemik tersendiri ketika adanya keterlibatan negara ke tiga dalam proses ekstradisi tersebut. Keterlibatan tersebut adalah ketika pelaku kejahatan yang menjadi obyek ekstradisi bukan merupakan warga negara dari negara peminta ataupun warga negara diminta.

Hal demikian pernah terjadi sebelumnya, yaitu kasus Lim Yong Nam. Ia merupakan seorang warga negara Singapura yang ditangkap oleh Pemerintah Indonesia atas permintaan 
Teddy Nurcahyawan \& Stevanus Rivaldo

Amerika Serikat. Lim Yong

Nam dituduh telah melakukan

perdagangan produk-produk

elektronik produksi Amerika

Serikat dengan Iran. Pada tahun 2016, akhirnya Lim

Yong Nam dipulangkan ke

Amerika Serikat oleh

Pemerintah Indonesia dengan dasar adanya hubungan baik antara Amerika Serikat dengan Indonesia. Ini sesuai dengan bunyi Pasal 2 ayat (2) Undang-Undang Republik Indonesia tentang Ekstradisi yang berbunyi: "Dalam hal belum ada perjanjian tersebut pada ayat (1) maka ekstradisi dapat dilakukan atas dasar hubungan baik dan jika kepentingan Negara Republik Indonesia menghendaki”. Dalam kasus tersebut terlihat bahwa kewarganegaraan tersangka yang berasal dari negara ke tiga tidak menjadi penghalang terhadap proses pengembalian tersangka ke negara peminta.

Polemik ini terjadi dalam kasus yang menimpa Meng
Wanzhou. Ia ditangkap oleh Pemerintah Kanada atas permintaan Amerika Serikat, sedangkan ia merupakan warga negara Tiongkok. Dalam kasus ini, kewarganegaraan Meng Wanzhou pun seharusnya tidak menjadi faktor penentu dalam proses ekstradisi yang berjalan. Hal ini didasarkan bahwa kewarganegaraan dari negara ketiga (bukan dari negara peminta ataupun diminta) tidak memiliki relevansi apapun terhadap proses ektradisi. ${ }^{29}$ ) Dalam Pasal 1 Perjanjian Ekstradisi Antara Amerika Serikat dan Kanada berbunyi:

"Each Contracting Party agrees to extradite to the other, in the circumtances and subject to the condition described in this Treaty, person found in its territory who have been charged with or covicted of, any of the offenses covered by

\footnotetext{
${ }^{29)}$ Ibid., hal 396.
} 
Article 2 of this Treaty committed within the territory of the other, or outside thereof under the condition specified in Article 3 (3) of these Treaty"

Secara umum dapat diartikan bahwa Para Pihak telah setuju untuk melakukan ekstradisi terhadap orang-orang yang telah dituntut ataupun telah didakwa oleh kejahatan yang sesuai dengan kondisikondisi di dalam perjanjian tersebut. Dalam bunyi pasal tersebut juga tidak didefinisikan siapa yang bisa diekstradisi dalam kaitannya dengan kewarganegaraan sehingga kewarganeraan tersebut tidak menjadi faktor penentu dalam proses ekstradisi.

Dengan demikian Tiongkok tentu tidak bisa meminta Meng
Wanzhou untuk

dikembalikan dengan

dasar

kewarganegaraanya.

Lain hal jika Meng

Wanzhou memiliki

kewarganegaraan

Kanada, dimana Kanada

dapat menolak

melakukan ekstradisi

berdasarkan asas tidak

mengekstradisi warga

negara sendiri.

\section{Penutup}

\section{A. Kesimpulan}

Berdasarkan uraian Peneliti, kita dapat menarik kesimpulan:

1. Bahwa permintaan Amerika Serikat untuk mengekstradisi Meng Wanzhou kepada Kanada adalah sesuai dengan prinsip-prinsip hukum internasional. Permintaan ekstradisi tersebut juga telah diatur dalam suatu perjanjian ekstradisi khusus antar kedua negara yaitu Extradition Treaty Betwenn United States and Canada. Permintaan ekstradisi tersebut juga telah 
memenuhi berbagai syarat yang ada dalam perjanjian tersebut.

Permintaan

Tiongkok

untuk mengembalikan Meng

Wanzhou ke negaranya

adalah hal wajar mengingat adanya prinsip nasionalitas aktif yang memberikan kewenangan kepad Tiongkok untuk melindungi warga negaranya yang sedang berada di luar negeri. Peneliti menyatakan hal ini adalah salah satu bentuk perlindungan Tiongkok terhadap warga negaranya dan pihak lain pun harus menghormati hal ini. Begitu pula Tiongkok harus menghormati Kanada dan Amerika Serikat yang telah terikat dengan sebuah perjanjian ekstradisi.

2. Mekanisme selanjutnya yang ditempuh oleh Amerika Serikat dan Kanada dalam melakukan proses ekstradisi adalah melalui jalur goverment to government. Setelah mendapat persetujuan ekstradisi dari Pemerintah Kanada, Amerika Serikat dapat melakukan penjemputan terhadap Meng Wanzhou oleh pihak berwenang yang ditunjuk oleh Pemerintah Amerika Serikat. Setelah sampai di wilayah Amerika Serikat, Meng Wanzhou harus diadili secara adil berdasarkna kejahatan yang dijadika dasar ekstradisi, tidak boleh atas kejahatan lainnya.

\section{B. Saran}

Melihat paparan Peneliti di atas, Peneliti memberikan saran sebagai berikut:

1. Dalam penyelesaian kasus ini, hendaknya para pihak menghindari berbagai cara yang berpotensi menimbulkan

ketidakstabilan di dunia. Ini mengingat bahwa negaranegara yang terlibat, yaitu: Amerika Serikat, Kanada, dan Tiongkok, adalah negara-negara yang berpengaruh besar terhadap 
kestabilan dunia, terutama

Amerika Serikat dan

Tiongkok.

2. Perihal ekstradisi, para pihak harus menghormati hukum serta prinsip-prinsip hukum internasional yang berlaku. Berbagai keberatan serta tanggapan hendaknya dilakukan melalui jalur-jalur diplomasi yang ada.

Demikianlah saran-saran yang dapat Peneliti berikan berdasarkan penelitian yang telah dilakukan.

\section{Daftar Pustaka}

\section{A. Buku}

Bantekas, Ilias dan Susan Nash International

Criminal

Law, :Cavendish Publishing, 2003).

Benjamin, Andrew, Walter Benjamin And Art, (London: Continuum, 2011).

Bassiouni, M. Cherif. International Extradition and World Public Order, (Alphen aan den Rijn: Kluwer Academic Publisher, 1974).
Diantha, I Made Pasek, Hukum Perjanjian Internasional, (Denpasar: Fakultas Hukum Universitas Udayana, 2017).

Mauna, Boer. Hukum Internasional:

Pengertian Peranan Dan Fungsi Dalam Era Dinamika Global, Edisi Ke-2, (Bandung: Alumni, 2005).

Parthiana, I Wayan. Esktradisi Dalam

Hukum

Internasional Modern, (Bandung: Yrama Widya, 2009).

Rothman, Fred B. International Criminal Law, (New York: Sweet and Maxwell, 1965).

Sunarso, Siswanto. Ekstradisi dan Bantuan Timbal Balik dalam Masalah Pidana: Instrumen Penegakan Hukum Internasional, (Jakarta: Rineka Cipta, 2009).

\section{B. Jurnal}

Aghazadeh, Mahdieh. "International Sanctions And Their Impact On Iran's Economy", International Journal of Economy And Finance Studies, Volume 6, No.2, 2014, Instanbul: Fatih University.

Artasasmita, Romli. "Ekstradisi dalam Meningkatkan Kerja Sama Penegakan Hukum", Indonesian Journal of International Law, Volume 3, Nomor 1, Oktober 2007. 


Ettinger, Aaron. “Trump's
National 'America
Strategy: Meets the
First'
Establishment",
Canada's Journal of
Global Policy Analysis,
September, 2018.
Fereira, Andre da Rocha et. al.
"The Obligation to
Extradite or Prosecute",
UFRGS Model United
Nations Journal, Volume
1, 2013, Porto Alegre:
Universidade Federal do
Rio Grande do Sul.

\section{Artikel}

Kompas. "Iran Tetap Bisa Jual Minyak", Kompas, 7 November 2018, hal. 8.

\section{Internet}

Azpiri, John. "Huawei CFO Meng Wanzhou Granted Bail, Will Live In Vancouver Under Electronic Survaillance" https://globalnews.ca/ne ws/4749540/mengwanzhou-huawei-bailhearing-day-3/ diakses pada tanggal 18 Desember 2018 pukul 20.36 .

Kuo, Lily. "China Demands Release of Huawei Executive Arrested In Canada", http://www.theguardian.co m/technology/2018/dec/05/ meng-wanzhou-huawei-cfoarrested-vancouver diakses pada tanggal 21 Januari 2019 pukul 14.45.

The United States Department Of Justice, "Singapore Man
Senteced To 40 Months in Prison for Plot Involving Exports To Iran of U.S. Components", http://www.justice.gov/opa/ prl singapore-mansenteced-to-40-month- inprison-for-plot-involvingexports-to-ira- of-uscomponents diakses pada tanggal 23 Februari 2019 pukul 20.15 .

Vebri. "4 Fakta Terbaru Setelah Bos Huawei Ditangkap: Mantan Diplomat Kanada Ditangkap di China", http://www.tribunnews.com /section/2018/12/14/4fakta-terbaru-setelah-boshuawei-ditangkap-mantandiplomat-kanada-ditahanchina diakses pada tanggal 21 Januari 2018 pukul 14.00 .

VOA Indonesia. "AS Mulai Berlakukan Sanksi Terhadap Iran", http://www.voaindonesia.c om/a/as-mulai-berlakukansanksi-terhadapiran/4515389.html diakses pada tanggal 21 Januari 2019 pukul 15.10.

Wakabayashi, Daisuke dan Alan Rapeport, "Huawei CFO Is Arrested In Canada For Estradition To The U.S.",

https://www.nytimes.com/2 018/12/05/business/huawei -cfo-arrest-canadaextradition.html diakses pada tanggal 18 Desember 2018 pukul 20.50 . 